\title{
PENYIDIKAN TERHADAP ANAK SEBAGAI PELAKU TINDAK PIDANA PELECEHAN SEKSUAL OLEH PENYIDIK UNIT PPA SATUAN RESKRIM BERBASIS KEADILAN RESTORATIF DI KABUPATEN KENDAL
}

\author{
Agil Widiyas Sampurna ${ }^{1}$, Suteki² \\ Program Studi Magister IImu Hukum \\ Fakultas Hukum Universitas Diponegoro
}

\begin{abstract}
ABSTRAK
Kasus pelecehan seksual seperti persetubuhan dan pencabulan yang terjadi di kabupaten Kendal sudah semakin marak dan mengkhawatirkan karena sudah sangat memungkinkan tindak pidana tersebut dilakukan oleh anak. Hal tersebut terjadi karena mudahnya akses pornografi melalui internet yang kemudian ditiru dan dipraktekkan oleh anak tersebut. Hal itu terbukti dengan adanya anak dibawah umur 12 (dua belas) tahun melakukan pelecehan seksual di kabuapten Kendal pada tahun 2015 dan akhirnya anak tersebut di vonis putusan pidana penjara oleh hakim, dimana hal tersebut tidak sesuai dengan sistem peradilan pidana anak. Sehingga, perlu dilakukan terobosan hukum dalam sistem peradilan pidana yang ada khususnya penyidikan yang dilakukan oleh kepolisian sebagai garda terdepan dalam penaganan tindak pidana berkaitan dengan anak. Metode pendekatan yang digunakan penulis adalah pendekatan Socio-Legal Research, sebagai suatu pendekatan alternatif yang menguji studi doktrinal terhadap hukum. Domain tersebut terdiri dari, Mengapa penyidikan terhadap anak sebagai pelaku tindak pidana pelecehan seksual oleh penyidik unit PPA cenderung mengikuti penyidikan konvensional dan tidak berbasis keadilan restoratif di kabupaten Kendal. Dan Bagaimana dampak dari penyidikan tersebut, serta Bagaimana konsep baru penyidikan terhadap anak sebagai pelaku tindak pidana pelecehan seksual oleh penyidik unit PPA yang berbasis keadilan restoratif. Hasil peneltian bahwa penyidikan terhadap anak sebagai pelaku tindak pidana pelecehan seksual oeh penyidik unit PPA cenderung mengikuti penyidikan konvensional karena ada alasan yang mendorong baik secara internal maupun eksternal, dampaknya dapat mengenai anak sebagai pelaku tindak pidana pelecehan seksual, aparat penegak hukum yang terlibat dalam perkara tersebut, dan hukum acara terkait proses penanganan anak sebagai pelaku tindak pidana pelecehan seksual khususnya dalam penyidikan. Konsep baru tentang penyidikan terhadap anak sebagai pelaku tindak pidana pelecehan seksual oleh penyidik unit PPA yang berbasis keadilan restoratif, yaitu melalui sistem penegakan hukum satu atap/one roof enforcement system (ORES) dengan beberapa persyaratan yang harus diperhatikan sehingga penyidik unit PPA dapat menerapkan konsep baru penyidikan melalui sistem tersebut.
\end{abstract}

\section{Kata Kunci : Anak; Keadilan Restoratif; Penyidik; Penyidikan; Unit PPA}

\footnotetext{
${ }^{1}$ Mahasiswa Program Studi Magister IImu Hukum UNDIP

2 Penulis Kedua, Penulis Koresponden
} 


\section{Pendahuluan}

Masyarakat Indonesia saat ini berada pada situasi dan kondisi sebagai masyarakat transisi, yang mana situasi masyarakatnya beralih dari sistem pemerintahan yang otoriter ke demokrasi melalui proses yang disebut reformasi. Adanya perubahan transisi tersebut juga berpengaruh pada perkembangan kehidupan yang berawal dari kehidupan tradisional menuju kehidupan modernisme, yang membawa dampak signifikan terhadap tata nilai sosiokultural pada sebagian besar masyarakat, seperti daerah yang sedang berkembang dan tata letaknya berbatasan dengan kota besar.

Kabupaten Kendal adalah salah satu kabupaten di Jawa Tengah dan merupakan kabupaten penyangga kota Semarang sebagai ibukota provinsi Jawa Tengah di berbagai aspek kehidupan khususnya aspek ekonomi karena letaknya berbatasan langsung dengan kota Semarang, berdasarkan data dari Badan Pusat Statistik (BPS) per tahun 2015 kabupaten Kendal memiliki jumlah penduduk 952.966 jiwa dengan luas wilayah $1002,23 \mathrm{~km}^{2}{ }^{3}$ Posisi kabupaten Kendal sebagai kabupaten penyangga perekonomian telah mendorong banyak orang dari luar kota atau luar pulau Jawa untuk mencari rezeki dan menanam investasi. Namun demikian, para pendatang tersebut ditengarai membawa karakter budaya yang dimiliki dan perkembangan teknologi yang

3Lihat Badan Pusat Statistik (BPS) Kabupaten Kendal online (http://kendalkab.bps.go.id/home) pada tanggal 09 Oktober 2016. begitu pesat membawa dampak para pendatang kurang memperhatikan karakter budaya masyarakat kabupaten Kendal sehingga menimbulkan dampak sosial dalam kehidupan bermasyarakat.

Dampak yang paling terasa sebagai akibat dari perubahan sosial yang sangat cepat menuju modernisasi adalah masalah perilaku delikuensi anak. Masalah perilaku delikuensi anak secara umum di Indonesia masih merupakan gejala sosial dan telah menimbulkan kekhawatiran dikalangan orang tua pada khususnya dan masyarakat pada umumnya. Bentuk-bentuk perilaku delikuensi anak seperti penyalahgunaan narkoba, pencurian, pemerkosaan, penganiayaan, tawuran, geng motor muncul kepermukaan. Gejala tersebut menunjukkan sebagai masalah aktual yang khas di setiap zamannya oleh karenanya menarik untuk ditelaah. Masalah perilaku deikuensi anak yang saat ini marak terjadi di kabupaten Kendal adalah pergaulan yang berakibat terjadinya pelecehan seksual, dimana bentuknya seperti persetubuhan dan pencabulan.

Persetubuhan dan pencabulan yang terjadi di kabupaten Kendal untuk pelakunya didominasi oleh anak-anak dan korbannya juga anak-anak dengan ditunjukkan dari data laporan kasus persetubuhan dan pencabulan yang ada di Kepolisian Resor (Polres) Kendal, tahun 2014 terjadi 22 kasus persetubuhan dan pencabulan dimana jumlahnya 10 kasus persetubuhan dan 12 kasus pencabulan, kemudian tahun 2015 terjadi 31 kasus persetubuhan dan pencabulan dimana jumlahnya 
10 kasus persetubuhan dan 21 kasus pencabulan dengan pelakunya mayoritas adalah anak-anak, selanjutnya tahun 2016 sampai dengan bulan September terjadi 24 kasus persetubuhan dan pencabulan dimana jumlahnya 10 kasus persetubuhan dan 14 kasus pencabulan, jadi ratarata setiap bulannya Polres Kendal menerima laporan 2 kasus persetubuhan dan pencabulan.

Latar belakang atau penyebab terjadinya kasus persetubuhan dan pencabulan yang pelakunya anak-anak adalah perkembangan terknologi yang memudahkan anak-anak mengakses situs-situs porno melalui internet dan kurangnya pengawasan dari orang tua karena mayoritas orang tua dari anak-anak tersebut berkeja di luar negeri sebagai tenaga kerja Indonesia di negara lain. Dari penjelasan data diatas bahwa pelaku kasus persetubuhan dan pencabulan di wilayah kabupaten Kendal adalah dimungkinkan anak-anak karena mudahnya akses situs-situs porno di internet bagi anak-anak yang mana melihat dari situs-situs porno tersebut anak-anak mencontoh dan melakukan perbuatan pelecehan seksual. Sehingga diperlukan prosedur penanganan hukum yang benar dan terpadu antara kepolisian, kejaksaan dan pengadilan dengan memperhatikan hak-hak anak khususnya dimulai dari proses penyidikan yang dilakukan oleh pihak kepolisian sebagai garda terdepan dalam sistem peradilan pidana.

Hal ini ditunjukkan adanya kasus yang ditangani oleh unit PPA Satuan Reskrim Polres Kendal, yaitu pada tanggal 10 bulan Agustus tahun 2015, Unit
PPA Satuan Reskrim Polres Kendal menerima laporan bahwa telah terjadi pencabulan yang dilakukan oleh anak-anak dan korbannya juga anak-anak. Pelaku anak tersebut berjumlah 2 orang atas nama KHOIRUL UMAM dan AJIB DARMAWAN, saat melakukan perbuatan tersebut pelaku berusia 11 tahun 6 bulan dimana status pelaku masih sebagai siswa kelas $X$ di SMP Negeri 3 Kendal, kemudian untuk korban atas nama ANGGRAYANI ADINDA RAMADHANI berusia 6 tahun dan statusnya sebagai siswa kelas 2 di SD Sukodono Kendal. Pelaku melakukan pencabulan kepada korban sebanyak 4 kali dimana yang pertama pada bulan Mei 2015 dan yang terakhir pada bulan juni 2015 dengan semua pencabulan tersebut dilakukan di dalam kamar kakak pelaku dalam rumah pelaku di dusun Karangmalang Rt 01 Rw 01 Kelurahan Sukodono Kecamatan Kota Kendal Kabupaten Kendal. Pelaku dan korban masih memiliki hubungan keluarga yaitu nenek korban kakak beradik dengan ayah pelaku dan rumah pelaku bersebelahan dengan rumah korban, kemudian pelaku mengetahui perbuatan cabul tersebut dari internet saat pelaku bermain internet di warnet.

Proses penyidikan dilakukan oleh Unit PPA Satuan Reskrim Polres Kendal karena pihak orang tua korban sangat tidak menerima perbuatan pelaku dan menginginkan pelaku di proses sesuai dengan hukum yang berlaku. Sistem peradilan pidana terhadap anak yang melakukan pelecehan seksual pun berjalan sampai dengan persidangan dan putusan oleh pengadilan mendasari tuntutan 
dari kejaksaan dimana putusannya yaitu pelaku atas nama KHOIRUL UMAM dinyatakan terbukti secara sah dan meyakinkan bersalah melakukan tindak pidana dengan sengaja mengancam anak untuk melakukan beberapa perbuatan cabul yang dipandang sebagai perbuatan berlanjut sebagaimana dakwaan alternatif kedua dari penuntut umum, menjatuhkan pidana terhadap anak tersebut dengan pidana penjara di Lapas Anak Kutoarjo selama 3 (tiga) tahun dan 6 (enam) bulan, menetapkan agar anak menjalani pelatihan kerja pada lembaga pelatihan kerja selama 6 (enam) bulan dan AJIB DARMAWAN dinyatakan terbukti secara sah dan meyakinkan bersalah melakukan tindak pidana dengan sengaja mengancam anak untuk melakukan beberapa perbuatan cabul yang dipandang sebagai perbuatan berlanjut sebagaimana dakwaan alternatif kedua dari penuntut umum, menjatuhkan pidana terhadap anak tersebut dengan pidana penjara di Lapas Anak Kutoarjo selama 2 (dua) tahun dan 6 (enam) bulan, menetapkan agar anak menjalani pelatihan kerja pada lembaga pelatihan kerja selama 3 (tiga) bulan harus menjalani hukuman penjara di Lembaga Pemasyarakatan Anak.

Penanganan perkara tersebut menunjukkan bahwa pihak kepolisian menerapkan proses penyidikan konvensional sebagaimana Peraturan Kabareskrim Polri Nomor 3 tahun 2014 tentang Standar Operasional Prosedur Pelaksanaan Penyidikan Tindak Pidana, sehingga memberikan dampak kepada anak sebagai pelaku tindak pidana pelecehan seksual tersebut mendapatkan vonis hukuman pidana penjara dan hal tersebut sangat bertolak belakang dengan amanat Undang-Undang Nomor 11 tahun 2012 tentang Sistem Peradilan Pidana Anak yang mengutamakan pendekatan keadilan restoratif terhadap anak yang berhadapan dengan hukum dalam hal ini sebagai pelaku tindak pidana. Maka dari itu, perlu adanya rumusan/konsep pelaksanaan proses penyidikan yang tidak konvensional dan sesuai dengan hukum acara sistem peradilan pidana anak bagi penyidik kepolisian dalam menangani perkara yang mana pelaku tindak pidana pelecehan sesksual adalah anak. Diharapkan Polisi tidak hanya mewujudkan tercapainya tujuan penegakan hukum yaitu keadilan, kepastian hukum dan kemanfaatan, namun juga mampu mewujudkan keadilan restoratif bagi anak yang berhadapan dengan hukum sebagai pelaku tindak pidana pelecehan seksual dengan menjadi polisi responsif, yakni secara konseptual mengutamakan tujuan bukan prosedur saja serta tidak terkungkung oleh aturan, sehingga menjadi polisi progresif yang tidak menabukan diskresi yang valid dalam pelaksanaan tugasnya termasuk tugas sebagai garda pertama dalam penanganan tindak pidana berkaitan dengan anak. ${ }^{4}$ Berdasarkan penjelasan tersebut diatas, maka penulis tertarik untuk meneliti Penyidikan Terhadap Anak Sebagai Pelaku Tindak Pidana Pelecehan Seksual Oleh Penyidik Unit PPA Satuan Reskrim Berbasis Keadilan Restoratif Di Kabupaten Kendal.

${ }^{4}$ Suteki. Opcit. hlm 67 
Sesuai dengan latar belakang permasalahan yang telah dikemukakan di atas, dapat dirumuskan permasalahannya adalah

1. Mengapa penyidikan terhadap anak sebagai pelaku tindak pidana pelecehan seksual oleh penyidik unit PPA satuan reskrim di kabupaten Kendal masih cenderung mengikuti penyidikan konvensional yang tidak berbasis keadilan restoratif?

2. Bagaimana dampak dari penyidikan terhadap anak sebagai pelaku tindak pidana pelecehan seksual oleh penyidik unit PPA satuan reskrim yang tidak didasarkan kepada keadilan restoratif di kabupaten Kendal?

3. Bagaimana konsep baru tentang penyidikan terhadap anak sebagai pelaku tindak pidana pelecehan seksual oleh penyidik unit PPA yang berbasis keadilan restoratif?

Penelitian menggunakan beberapa teori dan konsep yaitu teori budaya hukum, teori bekerjanya hukum, teori penegakan hukum, teori tujuan hukum, konsep dampak, konsep sistem peradilan pidana, konsep sistem penegakan hukum satu atap/one roof enforcement system (ORES) dan konsep keadilan restoratif.

Teori budaya hukum menjelaskan bahwa hukum pada dasarnya tidak hanya sekedar rumusan hitam di atas putih saja sebagaimana yang dituangkan dalam berbagai bentuk peraturan perundangundangan, tetapi hendaknya hukum dilihat sebagai suatu gejala yang dapat diamati dalam kehidupan masyarakat melalui pola tingkah laku warganya ${ }^{5}$. Hal ini berarti hukum sangat dipengaruhi oleh faktor-faktor non hukum seperti : nilai, sikap, dan pandangan masyarakat yang biasa disebut dengan kultur/budaya hukum. Adanya kultur/budaya hukum inilah yang menyebabkan perbedaan penegakan hukum di antara masyarakat yang satu dengan masyarakat lainnya ${ }^{6}$. Oleh karena itu, teori tersebut digunakan untuk menganalisa penyidik Unit PPA Satuan Reskrim dalam melaksanakan penyidikan terhadap anak sebagai pelaku tindak pidana pelecehan seksual harus memperhatikan dan mempedomani tata cara dan melihat tindak pidana tersebut secara komprehensif/dari segala sisi yang mana harus membedakan proses penyidikannya dengan orang dewasa sebagaimana yang diatur dalam undang-undang sistem peradilan pidana anak dengan mengutamakan pendekatan keadilan restoratif.

Penyidikan terhadap anak sebagai pelaku tindak pidana pelecehan seksual tentunya berbeda dengan orang dewasa sebagai pelakunya dan hal tersebut akan memberikan dampak tersendiri sebagaimana dijelaskan tentang dampak adalah pengaruh kuat yang mendatangkan akibat, baik akibat positif maupun akibat negatif. Pengaruh sendiri adalah suatu keadaan dimana ada hubungan timbal balik atau hubungan sebab akibat antara apa yang mempengaruhi dengan apa yang dipengaruhi.7 Dampak yang ditimbulkan tersebut

\footnotetext{
5 Ishaq. Opcit. hlm 10

${ }^{6}$ Loc.cit

7 Lihat Kamus Besar Bahasa Indonesia online, (http://www.kbbi.web.id) pada tanggal 09 Oktober 2016
} 
dapat berpengaruh kepada anak yang melakukan tindak pidana pelecehan seksual tersebut, aparat penegak hukum yang terlibat dalam perkara tersebut, bahkan hukum acara dalam proses penyidikan tindak pidana pelecehan seksual tersebut.

$\mathrm{Hal}$ itu terlihat dari perkara yang telah diangani oleh unit PPA sat reskrim Kendal sehingga anak sebagai pelaku tindak pidana pelecehan seksual mendapatkan vonis hukuman pidana penjara dari hakim, menunjukkan bahwa hal tersebut tidak sesuai dengan amanat yang ada terkait berkejanya hukum khususnya bagi anak dalam undang-undang No. 11 tahun 2012 dan bukanlah penegakan hukum yang sesuai bagi anak yang melakukan tindak pidana. Sehingga, dicermati adanya vonis hukuman dalam perkara tersebut menunjukkan terdapat hal-hal yang mempengaruhi sebagaimana teori bekerjanya hukum menjelaskan bahwa basis bekerjanya hukum adalah masyarakat, maka hukum akan dipengaruhi oleh faktor-faktor atau kekuatan sosial mulai dari tahap pembuatan sampai dengan pemberlakuan, serta dalam penegakan hukumnya juga dipengaruhi oleh faktorfaktor sebagaimana dijelaskan teori penegakan hukum bahwa menurut Soerjono Soekanto, Penegakan hukum adalah kegiatan menyerasikan hubungan nilai-nilai yang terjabarkan di dalam kaedah-kaedah yang mantap dan mengejawantahkan dan sikap tindak sebagai rangkaian penjabaran nilai tahap akhir, untuk menciptakan, memelihara, dan mempertahankan kedamaian pergaulan hidup. 8 Oleh karena itu, penyidikan terhadap anak sebagai pelaku tindak pidana pelecehan seksual harus menggunakan pendekatan keadilan restoratif, sehingga digunakan konsep keadilan restoratif. Kemudian juga digunakan konsep sistem peradilan pidana yang mana menyebutkan komponen-komponen dalam sistem tersebut wajib untuk bekerjasama seperti kepolisian, kejaksaan, pengadilan, dan lembaga pemasyarakatan dengan mengkhususkan melalui konsep sistem penegakan hukum satu atap/one roof enforcement system (ORES), yaitu menempatkan pengawas, penyidik, dan penuntut di bawah satu atap ${ }^{9}$. Selanjutnya digunakan juga teori tujuan hukum yang mana tujuan hukum yang dimaksud adalah untuk mencapai kemanfaatan yang sebesar-besarnya tanpa menyampingkan aspek keadilan distributifí, dimana keadilan distributif tidak menekankan pada persamaan tentang apa yang didapat, melainkan menekankan pada perimbangan antara apa yang didapat dengan apa yang seharusnya didapat sesuai dengan latar belakang yang dimiliki baik pendidikan, kemampuan, kedudukan, kekayaan, kelahiran dan sebagainya (proporsional). ${ }^{11}$

\footnotetext{
8 Ishaq. Dasar-dasar IImu Hukum. Jakarta. Sinar Grafika. 2008. hlm 244

9Ismail Rumadan, J urnal Hukum dan Peradilan, Volume 3, Nomor 3 Nopember 2014. Puslitbang Hukum dan Peradilan MA RI. hIm 243-252

${ }^{10}$ S. Juhaya Praja. Teori Hukum dan Aplikasinya. Bandung. CV. Pustaka Setia. 2011. hlm 179
}

${ }^{11}$ Loc. cit 
Permasalahan pertama, yaitu mengapa penyidikan terhadap anak sebagai pelaku tindak pidana pelecehan seksual oleh penyidik unit PPA satuan reskrim di kabupaten Kendal masih cenderung mengikuti penyidikan konvensional yang tidak berbasis keadilan restoratif, dianalisis dengan menggunakan teori budaya hukum dan aturan yang mengatur tentang penyidikan seperti KUHAP, Peraturan Kapolri Nomor 14 Tahun 2012 tentang manajemen penyidikan, dan Peraturan Kabareskrim Nomor 3 Tahun 2014 tentang standar operasional prosedur pelaksanaan penyidikan tindak pidana di lingkungan POLRI.

Permasalahan kedua, yaitu tentang bagaimana dampak dari penyidikan terhadap anak sebagai pelaku tindak pidana pelecehan seksual oleh penyidik unit PPA satuan reskrim yang tidak didasarkan kepada keadilan restoratif di kabupaten Kendal, dianalisis dengan menggunakan teori bekerjanya hukum, teori penegakan hukum, dan konsep dampak.

Permasalahan ketiga, yaitu tentang bagaimana konsep baru tentang penyidikan terhadap anak sebagai pelaku tindak pidana pelecehan seksual oleh penyidik unit PPA yang berbasis keadilan restoratif, dianalisis dengan menggunakan teori tujuan hukum, konsep keadilan restorative, konsep sistem peradilan pidana, dan konsep sistem penegakan hukum satu atap/one roof enforcement system (ORES).

\section{Metode Penelitian}

Metode pendekatan yang digunakan penulis adalah pendekatan socio-legal research, yaitu suatu pendekatan alternatif yang menguji studi doktrinal terhadap hukum. Kata "socio" dalam socio-legal studies mencerminkan keterkaitan antar konteks dimana hukum berada (an interface with a context within which law exists). ${ }^{12}$ Penelitian ini bersifat deskriptif analitis. Dalam penelitian ini menggambarkan masalah dan fakta yang berkaitan dengan penyidikan terhadap anak sebagai pelaku tindak pidana pelecehan seksual oleh penyidik unit PPA satuan reskrim berbasis keadilan restoratif di kabupaten Kendal. Jenis Data yang digunakan data primer dan Data sekunder. Teknik pengumpulan data merupakan cara yang digunakan peneliti untuk mendapatkan data dalam suatu penelitian. Dalam pengumpulan data ini dapat diperoleh dari hasil observasi, wawancara, dokumentasi, dan gabungan/triangulasi. ${ }^{13}$

\section{Pembahasan}

\section{A. Alasan yang Mendorong Penyidikan terhadap Anak sebagai Pelaku Tindak Pidana Pelecehan Seksual oleh Penyidik Unit PPA Satuan Reskrim di Kabupaten Kendal} Cenderung Mengikuti Penyidikan

\footnotetext{
12 Banakar, Reza dan Max Travers. Law, Sociology and Method dalam Reza Banakar \& Max Travers (ed). Theory and Method in Socio-Legal Research. Onati: Hart Publishing Oxford and Portland Oregon. 2005. hlm 26

13 Sugiyono. Metode Penelitian Kuantitatif Kualitatif dan R\&D. Bandung. Alfabeta. 2009. hlm 225
} 


\section{Konvensional Yang Tidak Berbasis Keadilan} Restoratif

Penyidikan terhadap anak sebagai pelaku tindak pidana pelecehan seksual oleh unit PPA sat reskrim di polres Kendal cenderung mengikuti penyidikan konvensional yang tidak berbasis keadilan restoratif. Hal tersebut ditunjukkan adanya penanganan perkara pelecehan seksual dengan tersangka anak dibawah umur 12 (dua belas) tahun atas nama KHOIRUL UMAM dan AJIB DARMAWAN mendapatkan vonis hukuman penjara di penjara anak kutoarjo masing-masing selama 3 (tiga) tahun 6 (enam) bulan dan 2 (dua) tahun 6 (enam) bulan, yang mana proses penyidikan yang dilakukan oleh penyidik unit PPA sesuai dengan Undang-Undang Nomor 8 Tahun 1981 tentang Hukum Acara Pidana, Peraturan Kapolri Nomor 14 Tahun 2012 tentang Manajemen Penyidikan Dan Peraturan Kabareskrim Polri Nomor 3 Tahun 2014 tentang Standar Operasional Prosedur Penyidikan Tindak Pidana, namun tidak sesuai dengan hukum acara pidana anak sebagaimana yang ada dan tertuang di dalam Undang-Undang Nomor 11 Tahun 2012 tentang Sistem Peradilan Pidana Anak dan Peraturan Pemerintah Nomor 65 Tahun 2015 tentang Pedoman Pelaksanaan Diversi dan Penanganan Anak yang Belum Berumur 12 (Dua Belas) Tahun. Artinya, bahwa penyidik unit PPA Sat Reskrim Polres Kendal kurang memahami dan mempedomani aturan penanganan terhadap anak yang melakukan tindak pidana pelecehan seksual hanya dengan mendasari aturan lama yang ada dan belum menerapkan aturan hukum yang baru serta mengatur khusus terkait penanganan terhadap perkara anak tersebut.

Oleh karena itu, dapat dikatakan penyidikan terhadap anak sebagai pelaku tindak pidana pelecehan seksual oleh unit PPA sat reskrim polres Kendal masih konvensional dengan tidak mengedepankan pendekatan keadilan restoratif sebagaimana amanat Undang-Undang Nomor 11 Tahun 2012 tentang Sistem Peradilan Pidana Anak dan Peraturan Pemerintah Nomor 65 Tahun 2015 tentang Pedoman Pelaksanaan Diversi dan Penanganan Anak yang Belum Berumur 12 (Dua Belas) Tahun yang telah ditetapkan.

Sesuai dengan pasal 21 ayat 1 dalam UndangUndang Nomor 11 Tahun 2012 tentang Sistem Peradilan Pidana Anak dan Pasal 67 dalam Peraturan Pemerintah Nomor 65 Tahun 2015 tentang Pedoman Pelaksanaan Diversi dan Penanganan Anak yang Belum Berumur 12 (Dua Belas) Tahun bahwa "dalam hal anak yang belum berumur 12 (dua belas) tahun melakukan atau diduga melakukan tindak pidana, penyidik, pembimbing kemasyarakatan, dan pekerja sosial profesional mengambil keputusan untuk: menyerahkannya kembali kepada orang tua/ wali; atau mengikutsertakannya dalam program pendidikan, pembinaan, dan pembimbingan di instansi pemerintah atau LPKS di instansi yang menangani bidang kesejahteraan sosial, baik di tingkat pusat maupun daerah, untuk waktu paling lama 6 (enam) bulan".

Berdasarkan kondisi fakta dan aturan yang ada tersebut, maka dapat dikatakan bahwa ada alasan 
atau argumentasi yang mendorong penyidikan cenderung tidak berbasis keadilan restoratif baik secara internal maupun eksternal, sehingga penulis akan menganalisa faktor internal maupun faktor eksternal dan memanfaatkan teori budaya hukum. Dicermati, bahwa faktor internal merupakan faktor yang mempengaruhi dari dalam organisasi penyidik unit PPA sat reskrim dan faktor eksternal adalah faktor yang mempengaruhi penyidik unit PPA dari lingkungan sekitar penyidik. Adapun faktor-faktor tersebut antara lain:

\section{a. Faktor Internal}

1) Sisi sumber daya manusia, terdapat beberapa faktor yaitu:

a) Penyidik unit PPA belum memahami sepenuhnya tata cara penyidikan terhadap anak sebagai pelaku tindak pidana pelecehan seksual, karena belum mengikuti pendidikan kejuruan tentang pelayanan perempuan dan anak;

b) Penyidik unit PPA belum mengetahui peraturan perundang-undangan yang baru tentang penanganan hukum terhadap anak dalam hal ini peraturan pemerintah nomor 65 tahun 2015 tentang pedoman pelaksanaan diversi dan penanganan anak yang belum berumur 12 (dua belas) tahun, karena tidak ada sosialisasi atau pemberitahuan tentang aturan tersebut oleh bagian hukum kepada penyidik unit PPA.

c) Pengawas penyidik belum berperan secara maksimal sebagaimana mestinya, karena pengawas penyidik juga belum memahami aturan yang baru tentang penanganan perkara anak sebagai pelaku tindak pidana dalam hal ini peraturan pemerintah nomor 65 tahun 2015 tentang pedoman pelaksanaan diversi dan penanganan anak yang belum berumur 12 (dua belas) tahun

2) Dari sisi sistem, terdapat beberapa faktor yaitu:

a) Aturan penyidikan terhadap anak yang khusus diatur dalam lingkungan organisasi kepolisian sebagaimana tata cara penyidikan dalam undang-undang sistem peradilan pidana anak belum ada, karena aturan yang ada dan dipedomani penyidik sekarang masih terkait penyidikan secara umum yaitu Peraturan Kapolri Nomor 14 Tahun 2012 tentang Manajemen Penyidikan, dan Peraturan Kabareskrim Polri Nomor 3 Tahun 2014 tentang Standar Operasional Prosedur Penyidikan Tindak Pidana

b) Fokus kegiatan atau pengkhususan kegiatan tentang pelatihan pelayanan perempuan dan anak sebagai kaderisasi penyidik di satuan reskrim polres Kendal belum ada, karena program latihan peningkatan kemampuan fungsi reskrim yang ada di sub bagian latihan bagian sumber daya manusia polres Kendal tidak masuk dan diatur secara khusus dalam program tersebut.

3) Dari sisi budaya, penyidik unit PPA belum mampu memberikan kemudahan prosedur dalam pelayanan penanganan perkara anak sebagai pelaku tindak pidana yang berlanjut sampai persidangan, karena penyidik masih 
beranggapan penanganan anak tersebut adalah hal yang sama dan biasa seperti penanganan terhadap orang dewasa sebagai pelaku.

\section{b. Faktor Eksternal}

1) Dari sisi keluarga korban, menuntut dan meminta kepada penyidik unit PPA untuk melanjutkan perkara sesuai dengan prosedur hukum yang berlaku dalam hal ini menjalankan sistem peradilan pidana, karena rasa kekecewaan dan kekhawatiran pelaku akan melakukan perbuatan tersebut lagi kepada korban maupun orang lain.

2) Dari sisi instansi dan masyarakat sekitar, keaktifan dari instansi samping yang berkaitan dengan kegiatan penanganan tindak pidana pelecehan seksual seperti dinas sosial dan Badan Pemberdayaan Perempuan dan Keluarga Berencana (BPPKB) Kabupaten Kendal dan pastisipasi masyarakat kurang, karena instansi terkait dan masyarakat sekitar belum memahami sepenuhnya penanganan anak sebagai pelaku tindak pidana.

3) Dari sisi budaya, orang tua masih kurang memberikan pengawasan kepada anaknya, karena mayoritas orang tua tersebut meninggalkan anaknya untuk bekerja ke luar negeri sebagai tenaga kerja Indonesia dan menitipkan anak tersebut untuk di asuh oleh orang lain seperti kakek dan neneknya yang dianggap biasa dalam kehidupan masyarakat.

Persoalan mendasar bagi penyidik unit PPA sebagaimana teori budaya hukum yaitu pertama, hukum sebagai suatu sistem dimana pedomanan penegakan hukum didasarkan pada grundnorm dalam suatu sistem nilai dan sebagai bagian dari masyarakat yang tidak dapat dipisahkan sehingga nilai-nilai tersebut tertuang dalam pasal-pasal di undang-undang sistem peradilan pidana anak belum diindahkan dan diterapkan secara optimal karena kurang pemahaman atau informasi terbaru terkait sistem peradilan pidana anak, yang mana hal tersebut

Kedua, persoalan penyidik unit PPA tentang fungsi hukum kaitannya dengan pengaruh budaya hukum, dimana saat ini hukum tidak cukup hanya berfungsi sebagai sontrol sosial saja, melainkan hukum diharapkan mampu untuk menggerakkan masyarakat agar bertingkah laku sesuai dengan pola baru demi tercapainya tujuan yang dicitacitakan. Oleh karena itu, penerapan hukum yang demikian bagi anak yang melakukan tindak pidana pelecehan seksual oleh penyidik unit PPA belum dapat memaksimalkan fungsi hukum yang ada dan anak sebagai generasi penerus bangsa tidak akan dapat mencapai tujuannya dengan baik karena diberikan ajaran pembalasan dengan dilakukan penyidikan yang berakhir dengan hukuman penjara dan bukan ajaran pemulihan sebagaimana pendekatan keadilan restoratif yang termaktub dalam Undang-Undang Nomor 11 Tahun 2012 tentang Sistem Peradilan Pidana Anak.

Ketiga, persoalan penyidik unit PPA menyangkut bagaimana cara pembinaan kesadaran hukum yang erat kaitannya dengan sikap para pelaksana hukum dalam hal ini penyidik 
unit PPA untuk bertindak sesuai dengan ketentuan hukum dan berfungsi sebagai jembatan yang menghubungkan antara peraturan hukum dengan tingkah laku anggota masyarakatnya. Sehingga, unit PPA selain daripada melaksanakan penyidikan terhadap anak sebagai pelaku tindak pidana pelecehan seksual juga harus mampu memberikan edukasi/pendidikan pengetahuan tentang penanganan perkara anak baik kepada masyarakat maupun pelaksana hukum itu sendiri, namun ketika penyidik unit PPA tidak mengikuti perkembangan hukum terkait penanganan anak sebagai pelaku tindak pidana tersebut, maka dapat terjadi dampak yang kurang baik seperti penyidik unit PPA yang kurang mengikuti perkembangan aturan sistem peradilan pidana anak sehingga dalam penyidikan perkara anak di bawah umur 12 (dua belas) tahun sebagai pelaku tindak pidana pelecehan seksual untuk anak sebagai pelaku tersebut harus menerima hukuman penjara di penjara anak dan belum maksimal dalam menjadi penghubung yang baik antara aturan hukum yang berlaku dengan anggota masyarakat.

\section{B. Dampak dari Penyidikan terhadap Anak} sebagai Pelaku Tindak Pidana Pelecehan

Seksual oleh Penyidik Unit PPA Satuan Reskrim yang Tidak Didasarkan Kepada Keadilan Restoratif Di Kabupaten Kendal

Anak sebagai generasi penerus bangsa memiliki tanggung jawab untuk melanjutkan pembangunan dalam kehidupan berbangsa dan bernegara. Namun, ketika anak melakukan perbuatan yang melanggar susila atau melakukan pelecehan seksual akan memasukkan dirinya ke dalam ranah hukum pidana yang berlaku di negara ini.

Anak yang menjadi tersangka dalam tindak pidana pelecehan seksual sebagaimana unsur perbuatan yang dilarang dalam undang-undang nomor 35 tahun 2014 tentang perubahan atas undang-undang nomor 23 tahun 2002 tentang perlindungan anak, sehingga harus menanggung konsekuensi atau resiko dari perbuatannya tersebut yaitu sanksi pidana. Akibat hukum terhadap perbuatan pelecehan seksual yang dilakukan oleh anak yaitu pada dasarnya terjadi suatu perkara dimana anak meniru perbuatan dari internet dan melakukan pelecehan seksual kepada anak yang lain karena ketidaktahuan anak bahwa telah berbuat melanggar aturan sebagaimana diatur dalam undang-undang perlindungan anak. Sehingga, anak yang melakukan pelecehan seksual tersebut masuk ke dalam ranah hukum positif negara, yakni ranah sistem peradilan pidana anak. Apabila dalam persidangan anak yang melakukan pelecehan seksual tersebut dinyatakan terbukti dan bersalah oleh hakim mendasari laporan dari korban maupun keluarga korban dan bukti bukti yang ada dalam perkara tersebut, maka anak tersebut dapat dikenakan hukuman/sanksi pidana sebagaimana diatur dalam undang-undang perlndungan anak dan sistem peradilan pidana anak tersebut. Namun demikian, proses hukum terhadap anak sebagai pelaku tindak pidana pelecehan seksual tidak hanya berimplikasi kepada anak yang melakukan tindak pidana tersebut, tetapi 
juga dapat berimplikasi kepada aparat penegak hukum yang terlibat di dalam penanganannya. Sehingga dapat dikatakan bahwa dampak dari penyidikan terhadap anak sebagai pelaku tindak pidana pelecehan seksual dapat berimplikasi kepada anak, aparat penegak hukum yang terlibat dalam perkara, dan hukum acara itu sendiri.

a. Dampak terhadap anak yang melakukan tindak pidana pelecehan seksual yaitu hukuman/sanksi penjara dan tindakan.

b. Dampak terhadap aparat penegak hukum yang terlibat dalam penanganan perkara anak sebagai pelaku tindak pidana pelecehan seksual dapat berupa sanksi pidana penjara jika penanganannya tidak sesuai dengan hukum acara dalam sistem peradilan pidana anak.

c. Dampak terhadap hukum acara terkait proses penanganan anak sebagai pelaku tindak pidana pelecehan seksual khususnya dalam penyidikan yaitu tata cara penyidikan yang diatur dalam undang-undang sistem peradilan pidana anak tidak terlaksana secara optimal, sehingga tata cara yang ada dalam aturan kepolisian saat ini berupa Peraturan Kapolri Nomor 14 tahun 2012 tentang manajemen penyidikan dan Peraturan Kabareskrim Polri Nomor 3 tahun 2014 tentang standar operasional prosedur pelaksanaan penyidikan tindak pidana perlu dilakukan penyesuaian dan dirubah dengan memasukkan tata cara penyidikan terhadap anak sebagaimana yang diatur dalam undang-undang sistem peradilan pidana anak.

\section{Konsep Baru tentang Penyidikan terhadap} Anak sebagai Pelaku Tindak Pidana Pelecehan Seksual oleh Penyidik Unit PPA yang Berbasis Keadilan Restoratif

Pembahas persoalan mengenai konsep baru tentang penyidikan terhadap anak sebagai pelaku tindak pidana pelecehan seksual oleh penyidik unit PPA yang berbasis keadilan restoratif penulis terlebih dahulu mengkajinya dari beberapa argumentasi yang melandasi pentingnya konsep baru penyidikan terhadap anak sebagai pelaku tindak pidana pelecehan seksual, kemudian penjelasan konsep baru penyidikan terhadap anak sebagai pelaku tindak pidana pelecehan seksual sebagaimana termaktub dalam Undang-Undang Nomor 11 Tahun 2012 tentang Sistem Peradilan Pidana Anak dan aturan pelaksananya berupa Peraturan Pemerintah Nomor 65 Tahun 2015 tentang Pedoman Pelaksanaan Diversi dan penanganan Anak yang Belum Berumur 12 (dua belas) Tahun yang mengedepankan keadilan restoratif, selanjutnya potensi penerapan konsep baru penyidikan terhadap anak sebagai pelaku tersebut.

\section{Argumentasi Pentingnya Konsep Baru Penyidikan terhadap Anak sebagai Pelaku Tindak Pidana Pelecehan Seksual}

Bahwa penyidikan terhadap anak sebagai pelaku tindak pidana pelecehan seksual yang ada di lingkungan kepolisian saat ini sudah tidak sesuai atau kurang relevan dan perlu dilakukan konsep baru penyidikan terhadap anak sebagai pelaku 
tindak pidana tersebut, dimana hal tersebut didorong oleh beberapa alasan, anata lain:

a. Aturan yang mengatur tentang penyidikan di kepolisian yaitu Peraturan Kapolri Nomor 14 Tahun 2012 tentang Manajemen Penyidikan dan Peraturan Kabareskrim Polri Nomor 3 Tahun 2014 tentang Standar Operasional Prosedur Penyidikan Tindak Pidana tidak sesuai dengan Undang-Undang Nomor 11 Tahun 2012 tentang Sistem Peradilan Pidana Anak dan aturan pelaksananya berupa Peraturan Pemerintah Nomor 65 Tahun 2015 tentang Pedoman Pelaksanaan Diversi dan penanganan Anak yang Belum Berumur 12 (dua belas) Tahun karena tata cara yang diatur dalam undang-undang nomor 11 tahun 2012 khususnya penyidikan terhadap anak sebagai pelaku tindak pidana belum termaktub dalam peraturan kapolri maupun peraturan kabareskrim tersebut.

b. Saat ini, sudah sangat memungkinkan anak melakukan tindak pidana pelecehan seksual karena mudahnya akses internet dalam hal pornografi yang secara tidak sadar ditiru oleh anak dan kurangnya pengawasan orang tua terhadap anak.

c. Perlunya peningkatan kerjasama dan keterpaduan dalam penanganan perkara anak sebagai pelaku tindak pidana pelcehan seksual oleh aparat penegak hukum sebagaimana program pemerintah saat ini bahwa perkara yang berkaitan dengan anak merupakan extra ordinary crime, sehingga dalam penanganannyapun perlu dilakukan upaya lebih untuk mencapai keadilan restoratif bagi anak yang berhadapan dengan hukum khususnya anak yang melakukan tindak pidana pelecehan seksual.

Alasan sebagaimana tersebut diatas menunjukkan bahwa pentingnya konsep baru penanganan tindak pidana pelecehan seksual terhadap pelaku anak. Dalam penelitian ini, peneliti mengusulkan konsep baru penyidikan terhadap anak sebagai pelaku tindak pidana pelecehan seksual sebagaimana amanat undang-undang nomor 11 tahun 2012 tentang sistem peradilan pidana anak yaitu melalui sistem penegakan hukum satu atap/one roof enforcement system (ORES).

\section{Konsep Baru Penyidikan terhadap Anak sebagai Pelaku Tindak Pidana Pelecehan Seksual}

Keadilan restoratif adalah sebuah bentuk keadilan yang menekankan pemulihan atau restorasi tiga pihak, yaitu korban, pelaku kejahatan, dan masyarakat. ${ }^{14}$, sebagaimana juga dijelaskan dalam pasal 1 angka 6 undang-undang nomor 11 tahun 2012 tentang sistem peradilan pidana anak dan dalam aturan pelaksana undang-undang tersebut pada pasal 1 angka 2 peraturan pemerintah nomor 65 tahun 2014 tentang pedoman pelaksanaan diversi dan penanganan anak yang belum berumur 12 (dua belas) tahun, yang isinya ${ }^{15}$ :

"Keadilan restoratif adalah penyelesaian perkara tindak pidana dengan melibatkan

14 Yoachim Agus Tridiatno. Opcit. hlm 26

$15 \mathrm{lbid}$. hlm 30 
pelaku, korban, keluarga pelaku/korban, dan pihak lain yang terkait untuk bersama-sama mencari penyelesaian yang adil dengan menekankan pemulihan kembali pada keadaan semula dan bukan pembalasan.

Pelaksanaan penyidikan berbasis keadilan restoratif telah diatur dalam undang-undang tersebut dalam pasal-pasalnya, namun melihat kondisi penanganan perkara dengan tersangka anak UMAM dan AJIB mengisyaratkan bahwa proses penyidikan berbasis keadilan restoratif tersebut tidak dilaksanakan secara maksimal sehingga menerima putusan hukuman penjara di penjara anak.

Mencermati hal tersebut, terlihat bahwa penyidik sudah melakukan upaya untuk komunikasi dengan keluarga korban sebelum proses penyidikan terhadap laporan orang tua korban di proses, namun saat itu penyidik tidak memanggil pihakpihak yang berkompeten dan terlibat dalam perkara tersebut seperti pelaku, kelauarga pelaku, petugas pembimbing kemasyarakatan, pekerja sosial atau petugas dinas sosial, dan tokoh masyarakat setempat, sehingga tujuan penegakan hukum dengan pendekatan keadilan restoratif terhadap anak yang melakukan tindak pidana pelecehan seksual tersebut belum dapat tercapai sebagaimana yang diharapkan dalam prakteknya. Namun demikian, diketahui pada tahun 2015 terdapat 2 (dua) laporan dan atau pengaduan dari orang tua korban tindak pidana pelecehan seksual dengan tersangka juga anak-anak dapat dilakukan upaya penyelesaian perkara di luar sistem peradilan pidana anak atau musyawarah dan proses penyidikan berbasis keadilan restoratif dapat dilaksanakan dan hasil yang dicapai sesuai dengan amanat undang-undang nomor 11 tahun 2012 tentang sistem peradilan pidana anak dimana menunjukkan adanya penyidikan berbasis keadilan restoratif.

Memperhatikan penanganan terhadap perkara tindak pidana pelecehan seksual yang dapat diselesaikan di luar sistem peradilan pidana anak tersebut dengan komunikasi dan sinergitas yang baik seluruh elemen yang berkompeten maka penulis menganalisa bahwa dapat dimunculkan konsep baru terkait penyidikan tersebut sebagaimana yang tata cara penyidikan yang telah diatur dalam undang-undang nomor 11 tahun 2012 tentang sistem peradilan pidana anak yaitu melalui sistem penegakan hukum satu atap/one roof enforcement system (ORES). Diketahui, bahwa One Roof Enforcement System (ORES)/ Sistem Penegakan Hukum Satu Atap adalah menempatkan pengawas, penyidik, dan penuntut di bawah satu atap, dimana memiliki tujuan untuk membentuk keterpaduan dalam sistem peradilan pidana melalui kerjasama yang baik antar elemen penegak hukum meskipun tidak melebur menjadi satu unit atau departemen atau menyatu dalam lembaga tersendiri, guna menciptakan strategi supaya setiap elemen dapat meningkatakan efisiensi kerjanya dan sekaligus bersatu padu dengan elemen yang lainnya untuk menciptakan tujuan bersama, dalam hal ini dapat terselenggaranya sistem peradilan pidana anak 
dalam perkara anak sebagai pelaku tindak pidana pelecehan seksual dengan menggunakan pendekatan keadilan restoratif.

Adapun penjelasan pelaksanaan garis besar secara teknis tentang konsep baru penyidikan terhadap anak sebagai pelaku tindak pidana pelecehan seksual sebagaimana termaktub dalam undang-undang nomor 11 tahun 2012 tentang sistem peradilan pidana anak dan peraturan pemerintah nomor 65 tahun 2015 tentang pedoman pelaksanaan diversi dan penanganan anak yang belum berumur 12 (dua belas) tahun yang mengedepankan keadilan restoratif yaitu, adanya laporan dan atau pengaduan tentang tindak pidana pelecehan seksual yang dilakukan oleh anak untuk pihak-pihak yang terlibat dalam proses penyidikan di sistem peradilan pidana anak seperti kepolisian, kejaksaan, petugas pembimbing kemasyarakatan, pekerja sosial atau petugas dinas sosial, dan tim pelayanan penanganan terpadu dari pemerintah daerah dalam waktu 1×24 jam melakukan pertemuan untuk memberikan saran kepada penyidik kepolisian guna menentukan langkah selanjutnya, jika pelaku anak masih berumur kurang dari 12 (dua belas) tahun maka elemen penegak hukum tersebut harus mempertemukan pihak korban dan pelaku untuk segera diambil keputusan sebagaimana aturan dalam undangundang dan dibuatkan ketetapan pengadilan dengan waktu paling lama 3 (tiga) hari.

Apabila pelaku anak berumur lebih dari 12 (dua belas) tahun kurang dari 18 (delapan belas) tahun, maka elemen penegak hukum dalam sistem tersebut melihat perkara yang terjadi dan melakukan proses hukum dengan tidak menghalangi pihak korban dan tersangka untuk melakukan penyelesaian melalui musyawarah yang mana jika ada kesepakatan dalam musyawarah maka proses tersebut dibuatkan kesepakatan bersama dan diajukan kepengadilan untuk dimintakan penetapan sebagai wujud kepastian hukum penyelesaian perkara tersebut dalam waktu 3 (tiga) hari, namun jika tidak tercapai kesepakatan maka poses hukum tetap berjalan sebagaimana mestinya sampai dengan adanya putusan dari pengadilan terhadap perkara tersebut. Proses penanganan perkara tersebut tetap harus memperhatikan umur anak sebagai pelaku tersebut dan tidak boleh melebihi waktu 1 (satu) bulan sampai dengan adanya putusan dalam hal perkara dilanjutkan sebagaimana sistem peradilan pidana anak.

Hal tersebut dimaksudkan untuk menjaga harkat dan martabat anak serta memelihara tumbuh kembanganak untuk tidak merasa tertekan ataupun memiliki rasa bersalah yang berlebihan sehingga menimbulkan ganguan baik fisik maupun psikis terhadap anak sebagai pelaku tindak pidana tersebut.

\section{Potensi Penerapan Konsep Baru Penyidikan} terhadap Anak sebagai Pelaku Tindak Pidana Pelecehan Seksual

Pentingnya penanganan tindak pidana pelecehan seksual terhadap pelaku anak melalui sistem penegakan hukum satu atap/one roof enforcement system (ORES) karena dorongan dari 
kondisi sekarang yang mana anak sangat mungkin menjadi pelaku tindak pidana pelecehan seksual sehingga kejahatan tersebut oleh pemerintah dinyatakan sebagai extra ordinary crime dan secara tersirat memberikan pesan perlu adanya penanganan yang ekstra juga terhadap kejahatan tersebut. One Roof Enforcement System (ORES)/ Sistem Penegakan Hukum Satu Atap adalah menempatkan pengawas, penyidik, dan penuntut di bawah satu atap.

Konsep baru penyidikan terhadap anak sebagai pelaku tindak pidana pelecehan seksual sebagaimana termaktub dalam undang-undang nomor 11 tahun 2012 tentang sistem peradilan pidana anak dan peraturan pemerintah nomor 65 tahun 2015 tentang pedoman pelaksanaan diversi dan penanganan anak yang belum berumur 12 (dua belas) tahun yang mengedepankan keadilan restoratif memperhatikan dan merupakan perwujudan beberapa prinsip-prinsip dasar keadilan restoratif, yaitu:

a. Keadilan restoratif mengutamakan pemulihan atau restorasi bagi semua pihak yangterkena dampak dari tindak kejahatan, yaitu korban, pelaku, dan masyarakat.

b. Berkaitan dengan cita-cita pemulihan di atas, keadilan restoratif fokus pada kebutuhan tiga pihak, yaitu korban, pelaku kejahatan, danmasyarakat yang tidak dipenuhi oleh proses peradilan.

c. Keadilan restoratif memperhatikan kewajiban dan tanggung jawab yang muncul oleh karena tindak kejahatan.
Oleh karena itu, terdapat beberapa persyaratan yang harus diperhatikan sehingga penyidik unit PPA dapat menerapkan konsep baru penyidikan melalui sistem penegakan hukum satu atap/one roof enforcement system (ORES) sebagaimana dijelaskan diatas, yaitu:

a. Aturan yang mengatur tentang penyidikan di kepolisian yaitu Peraturan Kapolri Nomor 14 Tahun 2012 tentang Manajemen Penyidikan dan Peraturan Kabareskrim Polri Nomor 3 Tahun 2014 tentang Standar Operasional Prosedur Penyidikan Tindak Pidana dirubah dan disesuaikan dengan tata cara penyidikan dalam Undang-Undang Nomor 11 Tahun 2012 tentang Sistem Peradilan Pidana Anak dan Peraturan Pemerintah Nomor 65 Tahun 2015 tentang Pedoman Pelaksanaan Diversi dan penanganan Anak yang Belum Berumur 12 (dua belas) Tahun sebagaimana teknis konsep baru penyidikan di atas

b. Pelaksanaan setiap tahapan dalam proses penyidikan diatur secara jelas dan mengikuti waktu yang telah diatur dalam undangundangsistem peradilan pidana seperti, waktu pelaksanaan sampai hasil penelitian yang dilakukan oleh petugas BAPAS atas permintaan penyidik tidak boleh lebih dari 3 (tiga) hari dan penetapan hasil musyawarah atau kesepakatan bersama yang dikeluarkan oleh pengadilan atas permintaan penyidik tidak boleh lebih dari 3 (tiga) hari.

c. Dibuat dan disepakatinya kesepakatan bersama atau Memorandum of Undertanding (MOU) 
antara aparat penegak hukum dalam sisitem peradilan pidana anak yang memuat tentang langkah-langkah dan tata cara pelaksanaan penanganan perkara anak sebagai pelaku tindak pidana secara terpadu dan sinergis berdasarkan tugas, tanggung jawab, dan kewenangan masing-masing aparat penegak hukum tersebut.

Berdasarkan persyaratan tersebut menunjukkan bahwa konsep baru penyidikan terhadap anak sebagai pelaku tindak pidana pelecehan seksual sebagaimana termaktub dalam undang-undang nomor 11 tahun 2012 tentang sistem peradilan pidana anak dan peraturan pemerintah nomor 65 tahun 2015 tentang pedoman pelaksanaan diversi dan penanganan anak yang belum berumur 12 (dua belas) tahun memiliki potensi untuk dapat diterapkan sehingga kedepan untuk penyidikan terhadap anak sebagai pelaku tindak pidana pelecehan seksual dapat menerapkan dan hasilnya sesuai dengan pendekatan keadilan restoratif dimaksud.

\section{Simpulan dan Saran}

\section{Simpulan}

1. Penyidikan terhadap anak sebagai pelaku tindak pidana pelecehan seksual oleh unit PPA Sat Reskrim Polres Kendal masih konvensional dengan tidak mengedepankan pendekatan keadilan restoratif, karena proses penyidikan yang dilakukan oleh penyidik unit PPA sesuai dengan Undang-Undang Nomor 8 Tahun 1981 tentang Hukum Acara Pidana, Peraturan Kapolri
Nomor 14 Tahun 2012 tentang Manajemen Penyidikan dan Peraturan Kabareskrim Polri Nomor 3 Tahun 2014 tentang Standar Operasional Prosedur Penyidikan Tindak Pidana, namun tidak sesuai dengan hukum acara pidana anak sebagaimana yang ada dan tertuang di dalam Undang-Undang Nomor 11 Tahun 2012 tentang Sistem Peradilan Pidana Anak dan Peraturan Pemerintah Nomor 65 Tahun 2015 tentang Pedoman Pelaksanaan Diversi dan Penanganan Anak yang Belum Berumur 12 (Dua Belas) Tahun. Oleh karena itu, dapat dikatakan bahwa ada alasan atau argumentasi yang mendorong penyidikan cenderung tidak berbasis keadilan restoratif baik secara internal maupun eksternal. Adapun faktor-faktor tersebut antara lain:

a. Faktor Internal

1) Dari sisi sumber daya manusia, terdapat beberapa faktor yaitu:

a) Penyidik unit PPA belum memahami sepenuhnya tata cara penyidikan terhadap anak sebagai pelaku tindak pidana pelecehan seksual, karena belum mengikuti pendidikan kejuruan tentang pelayanan perempuan dan anak;

b) Penyidik unit PPA belum mengetahui peraturan perundang-undangan yang baru tentang penanganan hukum terhadap anak dalam hal ini peraturan pemerintah nomor 65 tahun 2015 tentang pedoman pelaksanaan diversi dan penanganan anak yang belum berumur 12 (dua belas) tahun, karena tidak 
ada sosialisasi atau pemberitahuan tentang aturan tersebut oleh bagian hukum kepada penyidik unit PPA.

c) Pengawas penyidik belum berperan secara maksimal sebagaimana mestinya, karena pengawas penyidik juga belum memahami aturan yang baru tentang penanganan perkara anak sebagai pelaku tindak pidana dalam hal ini peraturan pemerintah nomor 65 tahun 2015 tentang pedoman pelaksanaan diversi dan penanganan anak yang belum berumur 12 (dua belas) tahun.

2) Dari sisi sistem, terdapat beberapa faktor yaitu:

a) Aturan penyidikan terhadap anak yang khusus diatur dalam lingkungan organisasi kepolisian sebagaimana tata cara penyidikan dalam undang-undang sistem peradilan pidana anak belum ada, karena aturan yang ada dan dipedomani penyidik sekarang masih terkait penyidikan secara umum yaitu Peraturan Kapolri Nomor 14 Tahun 2012 tentang Manajemen Penyidikan, dan Peraturan Kabareskrim Polri Nomor 3 Tahun 2014 tentang Standar Operasional Prosedur Penyidikan Tindak Pidana

b) Fokus kegiatan atau pengkhususan kegiatan tentang pelatihan pelayanan perempuan dan anak sebagai kaderisasi penyidik di satuan reskrim polres Kendal belum ada, karena program latihan peningkatan kemampuan fungsi reskrim yang ada di sub bagian latihan bagian sumber daya manusia polres Kendal tidak masuk dan diatur secara khusus dalam program tersebut.

c) Dari sisi budaya, penyidik unit PPA belum mampu memberikan kemudahan prosedur dalam pelayanan penanganan perkara anak sebagai pelaku tindak pidana yang berlanjut sampai persidangan, karena penyidik masih beranggapan penanganan anak tersebut adalah hal yang sama dan biasa seperti penanganan terhadap orang dewasa sebagai pelaku.

\section{b. Faktor Eksternal}

1) Dari sisi keluarga korban, menuntut dan meminta kepada penyidik unit PPA untuk melanjutkan perkara sesuai dengan prosedur hukum yang berlaku dalam hal ini menjalankan sistem peradilan pidana, karena rasa kekecewaan dan kekhawatiran pelaku akan melakukan perbuatan tersebut lagi kepada korban maupun orang lain.

2) Dari sisi instansi dan masyarakat sekitar, keaktifan dari instansi samping yang berkaitan dengan kegiatan penanganan tindak pidana pelecehan seksual seperti dinas sosial dan Badan Pemberdayaan Perempuan dan Keluarga Berencana (BPPKB) Kabupaten Kendal dan pastisipasi masyarakat kurang, karena instansi terkait dan masyarakat sekitar belum memahami sepenuhnya penanganan anak sebagai pelaku tindak pidana.

3) Dari sisi budaya, orang tua masih kurang memberikan pengawasan kepada anaknya, 
karena mayoritas orang tua tersebut meninggalkan anaknya untuk bekerja ke luar negeri sebagai tenaga kerja Indonesia dan menitipkan anak tersebut untuk di asuh oleh orang lain seperti kakek dan neneknya yang dianggap biasa dalam kehidupan masyarakat

2. Dampak dari penyidikan terhadap anak sebagai pelaku tindak pidana pelecehan seksual oleh penyidik unit PPA satuan reskrim yang tidak didasarkan kepada keadilan restoratif di kabupaten kendal tentunya berdampak terhadap pihak-pihak yang terkait dengan perkara anak sebagai pelaku tersebut, dimana hal tersebut dapat terjadi karena adanya beberapa faktor yang mempengaruhi yaitu faktor hukumnya sendiri, faktor penegak hukum, faktor sarana dan fasilitas yang mendukung penegakan hukum, faktor masyarakat, dan faktor kebudayaan. Oleh karena itu, dapat dikatakan bahwa dampak dari penyidikan terhadap anak sebagai pelaku tindak pidana pelecehan seksual dapat berimplikasi kepada anak, aparat penegak hukum yang terlibat dalam perkara, dan hukum acara itu sendiri, sebagai berikut:

a. Dampak terhadap anak yang melakukan tindak pidana pelecehan seksual yaitu hukuman/sanksi penjara dan tindakan.

b. Dampak terhadap aparat penegak hukum yang terlibat dalam penanganan perkara anak sebagai pelaku tindak pidana pelecehan seksual dapat berupa sanksi pidana penjara jika penanganannya tidak sesuai dengan hukum acara dalam sistem peradilan pidana anak.

c. Dampak terhadap hukum acara terkait proses penanganan anak sebagai pelaku tindak pidana pelecehan seksual khususnya dalam penyidikan yaitu tata cara penyidikan yang diatur dalam undang-undang sistem peradilan pidana anak tidak terlaksana secara optimal, sehingga tata cara yang ada dalam aturan kepolisian saat ini berupa Peraturan Kapolri Nomor 14 tahun 2012 tentang manajemen penyidikan dan Peraturan Kabareskrim Polri Nomor 3 tahun 2014 tentang standar operasional prosedur pelaksanaan penyidikan tindak pidana perlu dilakukan penyesuaian dan dirubah dengan memasukkan tata cara penyidikan terhadap anak sebagaimana yang diatur dalam undang-undang sistem peradilan pidana anak.

3. Konsep baru tentang penyidikan terhadap anak sebagai pelaku tindak pidana pelecehan seksual oleh penyidik unit PPA yang berbasis keadilan restoratif, yaitu melalui sistem penegakan hukum satu atap/one roof enforcement system (ORES) dengan membentuk dan menyususn tata cara penegakan hukum terhadap anak sebagai pelaku tindak pidana pelecehan seksual dengan terintegrasi dan terpadu antar komponen penegak hukum mendasari 
undang-undang no. 11 tahaun 2012 tentang sistem peradilan pidana anak dan peraturan daerah yang dibuat tentang tim pelayanan penanganan terpadu terkait perlindungan perempuan dan anak dari kekerasan. Konsep baru tersebut menekankan proses penanganan perkara terhadap anak sebagai pelaku tindak pidana pelecehan seksual tetap harus memperhatikan umur anak sebagai pelaku tersebut dan tidak boleh melebihi waktu 1 (satu) bulan sampai dengan adanya putusan dalam hal perkara dilanjutkan sebagaimana sistem peradilan pidana anak, dimana terdapat beberapa persyaratan yang harus diperhatikan sehingga penyidik unit PPA dapat menerapkan konsep baru penyidikan melalui sistem penegakan hukum satu atap/one roof enforcement system (ORES) sebagaimana dimaksud, yaitu:

a. Aturan yang mengatur tentang penyidikan di kepolisian yaitu Peraturan Kapolri Nomor 14 Tahun 2012 tentang Manajemen Penyidikan dan Peraturan Kabareskrim Polri Nomor 3 Tahun 2014 tentang Standar Operasional Prosedur Penyidikan Tindak Pidana dirubah dan disesuaikan dengan tata cara penyidikan dalam Undang-Undang Nomor 11 Tahun 2012 tentang Sistem Peradilan Pidana Anak dan Peraturan Pemerintah Nomor 65 Tahun 2015 tentang Pedoman Pelaksanaan Diversi dan penanganan Anak yang Belum Berumur 12 (dua belas) Tahun sebagaimana teknis konsep baru penyidikan di atas

b. Pelaksanaan setiap tahapan dalam proses penyidikan diatur secara jelas dan mengikuti waktu yang telah diatur dalam undangundangsistem peradilan pidana seperti, waktu pelaksanaan sampai hasil penelitian yang dilakukan oleh petugas BAPAS atas permintaan penyidik tidak boleh lebih dari 3 (tiga) hari dan penetapan hasil musyawarah atau kesepakatan bersama yang dikeluarkan oleh pengadilan atas permintaan penyidik tidak boleh lebih dari 3 (tiga) hari.

c. Dibuat dan disepakatinya kesepakatan bersama atau Memorandum of Undertanding (MOU) antara aparat penegak hukum dalam sisitem peradilan pidana anak yang memuat tentang langkah-langkah dan tata cara pelaksanaan penanganan perkara anak sebagai pelaku tindak pidana secara terpadu dan sinergis berdasarkan tugas, tanggung jawab, dan kewenangan masing-masing aparat penegak hukum tersebut.

\section{Saran}

1. Penyidik unit PPA Sat Reskrim Polres Kendal yang belum melaksanakan pendidikan kejuruan tentang pelayanan perempuan dan anak seharusnya untuk segera didaftarkan oleh bagian sumber daya manusia Polres Kendal untuk mengikuti pendidikan kejuruan tersebut, sehingga tidak terjadi penanganan hukum yang kurang maksimal dan memberikan dampak yang 
kurang baik bagi anak yang melakukan tindak pidana tersebut maupun aparat penegak hukum yang terlibat dalam penanganan tersebut.

2. Aturan internal organisasi kepolisian terkait penyidikan tindak pidana seperti peraturan kapolri nomor 14 tahun 2012 tentang manajemen penyidikan dan peraturan kabareskrim polri nomor 3 tahun 2014 tentang standar operasional prosedur pelaksanaan penyidikan tindak pidana di lingkungan kepolisian seharusnya diganti dan dirubah oleh Kapolri dan Kepala Badan Reserse Kriminal dengan memasukkan dan disesuaikan proses penyidikan terhadap anak sebagaimana tata cara penanganan anak dalam undang-undang nomor 11 tahun 2012 tentang sistem peradilan pidana anak dan peraturan pemerintah nomor 65 tahun 2015 tentang pedoman pelaksanaan diversi dan penanganan anak yang belum berumur 12 (dua belas) tahun, sehingga proses penyidikan terhadap anak oleh penyidik unit PPA Sat Reskrim Polres Kendal secara khusus dan Penyidik unit PPA di lingkungan kepolisian secara umum memiliki payung hukum yang sah dan dapat menerapkan penyidikan terhadap anak sebagai pelaku tindak pidana dengan mengedapankan pendekatan keadilan restoratif.

3. Kerjasama antara kepolisian dalam hal ini penyidik unit PPA dengan seluruh steak holder dan tokoh masyarakat dalam tim pelayanan terpadu penanganan kekerasan terhadap perempuan dan anak-anak di Kabupaten Kendal seharusnya lebih ditingkatkan lagi sehingga dapat menerapkan sistem penegakan hukum satu atap/one roof enforcement system (ORES), sebagai langkah pencegahan agar anak sebagai pelaku tindak pidana pelecehan seksual dapat berkurang dan penanganan hukumnya yang dimulai dari tahap penyidikan dapat menjadi awal yang baik dan tidak lagi bertentangan dengan undangundang yang ada.

\section{Daftar Pustaka}

\section{Sumber Buku :}

Ahmadi, Rulam. 2016. Metode Penelitian Kualitatif. Yogyakarta: Ar-Ruz Media.

Amiruddin dan H. Zaenal Asikin. 2008. Pengantar Metode Penelitian Hukum. Jakarta: Raja Grafindo Persada.

Avianti, Fransiska. 2008. Kebijakan PerundangUndangan Mengenai Badan Penyidik Dalam Sistem Peradilan Pidana Terpadu di Indonesia, Semarang: Magister IImu Hukum Univ. Diponegoro.

Djamin, Awaloedin. 1995. Manajemen Sumber Daya Manusia 1. Bandung: Sanyata Sumanasa Wira Sespim Polri.

Hiariej, Eddy 0.S.2009. Asas Legalitas \& Penemuan Hukum Dalam Hukum Pidana. Jakarta: Erlangga. 
Hasibuan, Malayu S.P.. 2005. Manajemen Sumber

Daya Manusia Edisi Revisi. Jakarta: Bumi Aksara.

Hamzah, Andi. 2002. Hukum Acara Pidana. Jakarta: Sinar Grafika.

Ishaq. 2008. Dasar-dasar Ilmu Hukum. Jakarta:

Sinar Grafika.

Jimly Asshiddiqie, Ali Safa'at. 2012. Teori Hans

Kelsen Tentang Hukum. Jakarta: Konstitusi Press.

John W. Creswell. 2010. Research Design Pendekatan Kualitatif, Kuantitatif, dan Mixed, (terjemahan oleh Achmad Fawaid). Yogyakarta: Pustaka Pelajar.

Marzuki, Peter Mahmud. 2005. Penelitian Hukum. cet.1. Jakarta: Prenada Media.

Mertokusumo, Sudikno. 2010. Mengenal Hukum Suatu Pengantar, edisi revisi, Yogyakarta: Cahaya Atma Pusaka.

Moleong, Lexy J. 2004. Metode Penelitian Kualitatif. Bandung: Rosda.

Praja, S. Juhaya. 2011. Teori Hukum dan Aplikasinya. Bandung: CV. Pustaka Setia.

S. Nasution. 2003. Metode Penelitian Naturalistik Kualitatif. Bandung: Tarsito.

Setiawan, Doni. 2012. Urgensi Peradilan Restoratif Dalam Hukum Pidana Anak Indonesia. Semarang: Unissula Press.

Soekanto, Soerjono. 2004. Pengantar Penelitian Hukum. cet.3. Jakarta: UI Press.

Sugiyono. 2009. Metode Penelitian Kuantitatif Kualitatif dan R\&D. Bandung: Alfabeta.
Suratman dan Philips Dillah. 2014. Metode Penelitian Hukum. Bandung: Alfabeta.

Suteki. 2015. Masa Depan Hukum Progresif. Yogyakarta: Thafa Media.

W. Gulo. 2002. Metode Penelitian. Jakarta: Gramedia.

Tridiatno, Yoachim Agus. 2015. Keadilan Restoratif. Yogyakarta: Cahaya Atma Pustaka.

\section{Sumber Artikel dan J urnal :}

Sumarni, DW. \& Setyowati. 1999. Pelecehan Tenaga Kerja Perempuan. Yogyakarta: Ford Foundation \& Pusat Penelitian Kependudukan UGM.

Banakar, Reza dan Max Travers. 2005. Law, Sociology and Method dalam Reza Banakar \& Max Travers (ed). Theory and Method in Socio-Legal Research. Onati: Hart Publishing Oxford and Portland Oregon.

Ismail Rumadan. 2014. Jurnal Hukum dan Peradilan, Volume 3, Nomor 3 Nopember 2014. Puslitbang Hukum dan Peradilan MA RI.

Zulkarnaen Koto. 2011. Terobosan Hukum dalam Penyederhanaan Proses Peradilan Pidana, Jurnal Studi Kepolisian, STIK, Jakarta.

\section{Sumber Produk Lembaga :}

Redaksi Sinar Grafika. 2010. Undang-undang Hukum Acara Pidana (UU RI No.8 tahun 1981), Jakarta: Sinar Grafika. 
Jurnal Law Reform

Volume 12, Nomor 1, Tahun 2016
Program Studi Magister Ilmu Hukum Fakultas Hukum Universitas Diponegoro

Fokusindo Mandiri. 2012. Undang-Undang Sistem Peradilan Pidana Anak dan Perlindungan Anak. Bandung: Fokusindo Mandiri.

Kementrian Pemberdayaan Perempuan dan Perlindungan Anak RI, Undang-undang Nomor 11 Tahun 2012 tentang Sistem Peradilan Pidana Anak dan Peraturan Pemerintah Nomor 65 Tahun 2015 tentang Pedoman Pelaksanaan Diversi dan Penanganan Anak di bawah Umur 12 (dua belas) Tahun. Deputi Bidang Perlindungan Anak, Cetakan ke 3 Tahun 2016.

\section{Sumber Internet :}

http://kendalkab.bps.go.id/hom, 09 Oktober 2016. http://mohammadhidayat_sh_sik_mh.com/PERATU RAN_KEPOLISIAN_YANG_SUDAH_DISAH KAN_KAPOLRI/PERRATURAN_KAPOLRI PERKAP_NO 10 TH 2007.pdf., 09 Oktober 2016.

http://id.shvoong.com/socialsciences/sociology/2205936-pengertianpelaksanaan-actuating, 09 Oktober 2016. http://www.kbbi.web.id, 09 Oktober 2016 